\title{
Meteorological and Geomagnetic Factors and Human Cardiovascular Diseases
}

\author{
Panasyuk M.V., ${ }^{1, *}$ Steshina E.G. ${ }^{2}$ Pudovik E.M. ${ }^{1}$ \\ ${ }^{1}$ Department of Geography and Cartography, Kazan Federal University, Kazan, Russia \\ ${ }^{2}$ Research Institute of Systemic Medicine, GAUZ "Interregional Clinical diagnostic center», Kazan, Russi \\ *Corresponding author. Email: mp3719@yandex.ru
}

\begin{abstract}
The article discusses the analysis of the influence of meteorological and geomagnetic factors on the human cardiovascular diseases within 2014-2018 at the "Regional Clinical Diagnostic Center" of Kazan. The study contains results of a statistical analysis of meteorological and geomagnetic factors and the indicators of the health conditions, as well as the responses obtained through survey according to the SF-36 "Quality of Life" method. The patients under study had serious problems of the cardiovascular system and entailing hospitalization. According to the sample, there are groups of patients with correlating values of meteorological indicators, indicators of geomagnetic activity and indicators of health status identified. These include groups of women with a diagnosis of Angina pectoris aged 46 years and older. The main meteorological and geomagnetic factors for these groups were the duration of the magnetic storm and the magnitude of atmospheric pressure. In the group of men up to 45 years with increased meteosensitivity, the main factors affecting the state of health became temperature and humidity. Statistical analysis showed that lethal factors include the duration of a magnetic storm and temperature conditions.
\end{abstract}

\section{Keywords: cardiovascular disease, meteorological and geomagnetic factors, health indicators}

\section{INTRODUCTION}

Cardiovascular disease (CVD) is considered one of the leading causes of death worldwide. Heart attacks and strokes are usually acute diseases. The cardiovascular system is one of the first to be included in the body's adaptation to external conditions, which is manifested in changes in the circulatory system, particularly, changes in vascular wall tone, rheological properties of blood and disorders in coagulation and anticoagulation systems.

The main risk factors for heart disease and stroke are malnutrition, physical inactivity, tobacco and alcohol use. Along with these factors, which form the main CVD risks, the researchers repeatedly noted and evaluated the influence of meteorological and geomagnetic factors on the overall incidence $[1,4,5,12]$. Modern processes of global climate change, accompanied by increasing instability of weather conditions, have increased attention to the analysis of the influence of these factors on the health condition of the population. Exposure to weather conditions and geomagnetic activity can cause physiological stresses, including sympathetic activation, hyper coagulation, and infections. This increases the incidence and mortality from cardiovascular diseases $[6,7]$. Tissue and organ atrophy takes place in the human body gradually; therefore, older people are usually more vulnerable to these influences than the younger generation $[10,13]$.
Among the most significant meteorological and geomagnetic factors for health are known temperature, atmospheric pressure, humidity, time of occurrence, strength and duration of magnetic storms. Climatic features of the natural zone, seasonal changes in the vitamin composition of food, the nutrition, etc. can also affect the functional state of the body $[1,8]$.

\section{METHODS AND MATERIALS}

The aim of the study is to analyze the influence of meteorological factors (air temperature, atmospheric pressure, air humidity) and geomagnetic factors (index of geomagnetic activity, time of onset of a magnetic storm or lag between its onset and hospitalization, duration of a magnetic storm) on exacerbation of cardiovascular diseases leading to hospitalization.

The main task was to study severe and critical cases with the occurrence of serious problems of the cardiovascular system and entailing hospitalization.

The main study was carried out as part of a statistical (correlation and regression) analysis of the tightness of the connection between meteorological indicators, geomagnetic activity indicators, and indicators of assessing the functional state of patients that were received as part of the emergency care at the Kazan Interregional Clinical Diagnostic Center in 2014-2018.

The total sample included data on 4294 patients with diagnoses: 
- ICD-10 I20 “Angina pectoris” (2304 patients);

- ICD-10 I21 "Myocardial infarction", including ICD-10 I22 "Repeated myocardial infarction" (1990 patients).

An additional study was conducted on a sample of 795 patients diagnosed with ICD I20 "Angina pectoris", ICD I21 "Myocardial infarction", including ICD I22 "Repeated myocardial infarction", hospitalized in 2017 at the Kazan Interregional Clinical Diagnostic Center. In this sample, the data, in addition to meteorological indicators and indicators of geomagnetic activity, functional health status, also included indicators of subjective assessment of the patient's health status, obtained using the international questionnaire SF-36 "Quality of life" [9].

During the research, daily geomagnetic data were used, made publicly available by the US Space Weather Prediction Center (NOAA) and Weather Schedule (LLC) $[3,11]$.

To assess the impact of meteorological factors, we used indicators of air temperature, ${ }^{\circ} \mathrm{C}$; humidity \%; atmospheric pressure, $\mathrm{mmHg}$.

The analysis of the influence of meteorological and geomagnetic factors on the health condition and on patients with CVD was carried out using non-parametric statistical methods and calculating Spearman's rank correlation coefficients at a statistical level of $95 \%$ $(\mathrm{p}<0.05)$. Problem solving was carried out according to general samples, in four age groups of patients (from 30 to 45 years old, from 46 to 60 years old, from 61 years to 69 years old, 70 years and older), in the subgroups "age group - men", "age group - women", as well as in the subgroups "age group - diagnosis" and" age group gender - diagnosis".

There are also classified both general patient samples according to functional state indicators and subjective health status indicators based on cluster analysis methods (hierarchical clustering methods and k-means method) to identify relatively homogeneous groups in order to search for intragroup correlation dependencies.

\section{RESULTS}

The study presents a correlation analysis of the meteorological and geomagnetic activity indicator values and as well as the health condition of patients with CVD. Results showed a low tightness of the connection of these indicators as for the general sample for assessing the functional state of patients in 2014-2018 $(\mathrm{n}=4294)$, and for a sample that includes information about a subjective assessment of the state of health $(\mathrm{n}=795)$.

The physiological and psychological features both men and women were divided into two corresponding subsamples according to the degree of subjective assessment of the influence of meteorological and geomagnetic factors on the general health condition. Further, within the results of previous studies [2, 8], patients were divided by age groups according to their classification by cardiology profile - from 30 to 45, from 46 to 60 , from 61 to 69 , from 70 years old and over.

In addition, to increase the homogeneity of the analyzed data among patients with a diagnosis of ICD-10 I21 Myocardial infarction, incl. ICD-10 I22 "Repeated myocardial infarction" there was a classification of patients according to the health indicators based on cluster analysis methods (hierarchical clustering methods and kmeans method). There were 3 groups of both women and men (clusters) identified which differ in terms of functional health status. In hospitalized patients with a diagnosis of ICD I20 "Angina pectoris", there were revealed 2 groups of men, and 3 groups of women. All of the patients have significant differences in functional health indicators.

Patients belonging to different groups of the functional state react differently to the occurrence of geomagnetic disturbances or changes in meteorological conditions. For this purpose, for each group, based on calculations of Spearman's rank correlation coefficients, the study revealed a correlation analysis of the relationships between meteorological, geomagnetic activity and functional state indicators.

For all the patient grouping options received by the MCC in 2014-2018, there is no statistical relationship between the functional state indicators (NPV, heart rate, upper blood pressure, lower blood pressure), meteorological indicators (temperature, atmospheric pressure, humidity), and geomagnetic activity indicators (index of geomagnetic activity, duration of a magnetic storm (number of days).

There is a similar analysis done based on the allocation of groups by gender, age and diagnosis, as well as on the basis of clustering results by a combination of indicators for a sample of 795 patients hospitalized at the State Children's Healthcare Institution in Moscow at the ICDC in 2017. The composition of the sample indicators, along with indicators of assessing the functional state, was supplemented by indicators of subjective assessment of the state of health (table 3 ). The data were collected according to the results of a sociological survey conducted according to the international method SF-36 "Quality of life" [9]. In this sample, individual groups of patients were identified with correlating values of meteorological indicators, indicators of geomagnetic activity and indicators of the health status of patients.

This is typical for women in the age group of 46-60 years, hospitalized with a diagnosis of ICD-10 I20 "Angina" with a direct correlation (for $r \geq 0.5 ; p<0.05$ ) of indicators:

1) "Lower HELL" - "Humidity";

2) "Feeling of cheerfulness" - "Humidity";

3) "Feeling of depression" - "Index of geomagnetic activity";

4) Weather sensitivity (questionnaire question "Do you feel a change in the weather?") - "Index of geomagnetic activity" (table 1). 
Table 1 Spearman rank correlation coefficient for women (46-60 years) with ICD I20 Angina pectoris diagnosis $(n=19)$. Notes correlations significant at level $\mathrm{p}<0.05000$

\begin{tabular}{|c|c|c|c|c|c|}
\hline Indicator & $\begin{array}{c}\text { Geomagnetic activity } \\
\text { index }\end{array}$ & $\begin{array}{l}\text { Magnetic storm } \\
\text { duration (days) }\end{array}$ & $\begin{array}{c}\text { Air } \\
\text { temperature }\end{array}$ & $\begin{array}{c}\text { Atmospheric } \\
\text { pressure }\end{array}$ & $\begin{array}{c}\text { Air } \\
\text { humidity }\end{array}$ \\
\hline \multicolumn{6}{|c|}{ Functional health assessment } \\
\hline Respiratory rate & 0.241701 & -0.666667 & 0.225674 & 0.014766 & -0.277792 \\
\hline Heartbeat rate & 0.123821 & 0.288675 & 0.162376 & -0.010301 & -0.191684 \\
\hline Pulse & 0.123821 & 0.288675 & 0.162376 & -0.010301 & -0.191684 \\
\hline Upper blood pressure & 0.051030 & -0.444262 & 0.129940 & 0.132683 & 0.428325 \\
\hline Lower blood pressure & 0.115968 & -0.148087 & -0.076449 & 0.316771 & 0.557677 \\
\hline \multicolumn{6}{|l|}{ Subjective health assessment } \\
\hline General health condition & -0.179756 & -0.645497 & 0.073332 & -0.021035 & -0.262939 \\
\hline Heavy physical work & 0.073288 & -0.612372 & 0.136920 & -0.154127 & -0.268680 \\
\hline Normal physical work & 0.237749 & 0.166667 & 0.372734 & -0.188147 & -0.410077 \\
\hline $\begin{array}{l}\text { How painful was the work } \\
\text { for you? }\end{array}$ & 0.132616 & 0.645497 & 0.131388 & 0.137464 & 0.118025 \\
\hline How long did it long? & 0.172967 & 0.408248 & 0.276821 & 0.052937 & -0.198515 \\
\hline How alert were you? & -0.325365 & 0.000000 & -0.358223 & 0.129256 & 0.518997 \\
\hline How anxious were you? & 0.385285 & -0.322749 & -0.079524 & -0.333247 & -0.126356 \\
\hline Did you feel depressed? & 0.499981 & 0.0325820 & 0.138596 & -0.384456 & -0.268501 \\
\hline Did you feel relaxed? & 0.270517 & 0.666667 & 0.230376 & -0.182056 & -0.116791 \\
\hline Did you feel happy? & 0.293383 & 0.666667 & 0.069053 & -0.237541 & 0.010211 \\
\hline Did you feel tired? & -0.299929 & 0.152145 & -0.278515 & 0.290017 & 0.391886 \\
\hline $\begin{array}{l}\text { Do you feel the climate } \\
\text { change? }\end{array}$ & 0.516323 & 0.152145 & 0.190690 & -0.314060 & -0.371602 \\
\hline
\end{tabular}

Women aged 61-69 with a ICD-10 I20 Angina pectoris diagnosis: there is a direct correlation (for $r \geq 0.5$; $\mathrm{p}<0.05$ ) of indicators of a subjective health assessment and the magnetic storm duration including:

1) Anxiety

2) Depression

3) Weather sensitivity

There is an inverse correlation between the feeling of fatigue and the magnetic storm duration revealed (table 2).

So, women diagnosed with Angina pectoris in this age group, geomagnetic activity is the main factor in anxiety, depression, fatigue, and general deterioration of health.

Correlation between meteorological indicators, indicators of geomagnetic activity and indicators of subjective health assessment was also found in the group of women with a diagnosis of Angina pectoris over 70 years of age. In this group, the main external factor in assessing health condition was the magnetic storm duration. There is an inverse correlation $(r \geq 0.5, p<0.05)$ observed between the indicators:

1) The magnetic storm duration - NPV

2) The magnetic storm duration - Upper blood pressure

A direct correlation is revealed $(\mathrm{r} \geq 0.5 ; \mathrm{p}<0.05)$ between the indicators:

3) The magnetic storm duration - Feeling relaxed

4) The magnetic storm duration - Feeling of happiness 
Table 2 Spearman rank correlation coefficient for women (61-69 years) with ICD I20 Angina pectoris diagnosis. Notes correlations are significant at level $\mathrm{p}<0.05000(\mathrm{n}=55)$

\begin{tabular}{|c|c|c|c|c|c|}
\hline Indicator & $\begin{array}{l}\text { Geomagnetic } \\
\text { activity index }\end{array}$ & $\begin{array}{l}\text { Magnetic storm } \\
\text { duration (days) }\end{array}$ & Air temperature & $\begin{array}{l}\text { Atmospheric } \\
\text { pressure }\end{array}$ & Air humidity \\
\hline \multicolumn{6}{|c|}{ Functional health assessment } \\
\hline Respiratory rate & -0.075588 & 0.162921 & -0.151223 & 0.215441 & -0.048939 \\
\hline Heartbeat rate & 0.190597 & -0.175812 & -0.001920 & -0.117443 & 0.210222 \\
\hline Pulse & 0.190597 & -0.175812 & -0.001920 & -0.117443 & 0.210222 \\
\hline Upper blood pressure & -0.166874 & 0.336573 & 0.000652 & 0.020208 & -0.036770 \\
\hline Lower blood pressure & -0.023727 & 0.138195 & 0.153431 & -0.044341 & -0.059738 \\
\hline \multicolumn{6}{|c|}{ Subjective health assessment } \\
\hline $\begin{array}{l}\text { General health } \\
\text { condition }\end{array}$ & 0.202685 & 0.713933 & 0.052922 & -0.001322 & -0.188390 \\
\hline Heavy physical work & 0.066757 & 0.382517 & 0.003772 & 0.003805 & -0.130589 \\
\hline $\begin{array}{l}\text { Normal physical } \\
\text { work }\end{array}$ & 0.081668 & 0.683243 & 0.100755 & 0.028249 & -0.088331 \\
\hline $\begin{array}{l}\text { How painful was the } \\
\text { work for you? }\end{array}$ & -0.129426 & -0.713933 & -0.028470 & 0.148124 & 0.003966 \\
\hline How long did it long? & -0.138623 & 0.066127 & 0.033657 & 0.012249 & -0.107171 \\
\hline How alert were you? & 0.024435 & -0.382517 & -0.116473 & 0.125985 & 0.017753 \\
\hline $\begin{array}{l}\text { How anxious were } \\
\text { you? }\end{array}$ & 0.107129 & 0.713933 & -0.037745 & -0.018959 & 0.003966 \\
\hline $\begin{array}{l}\text { Did you feel } \\
\text { depressed? }\end{array}$ & 0.068431 & 0.662539 & 0.039353 & 0.005738 & 0.034253 \\
\hline Did you feel relaxed? & 0.025805 & 0.577350 & 0.090107 & 0.127657 & 0.040479 \\
\hline Did you feel happy? & 0.077647 & 0.577350 & 0.027662 & 0.187426 & 0.095220 \\
\hline Did you feel tired? & -0.015171 & -0.683243 & -0.087267 & 0.058171 & 0.005966 \\
\hline $\begin{array}{l}\text { Do you feel the } \\
\text { weather changes? }\end{array}$ & 0.068431 & 0.662539 & 0.039353 & 0.005738 & 0.034253 \\
\hline
\end{tabular}

Thus, that short-term magnetic storms with high geomagnetic activity have a more negative impact on the health assessment than long-term magnetic storms with lower activity.

As part of a statistical analysis of 795 patients hospitalized in 2017, there was a group of particularly weather-sensitive patients identified $(n=520)$. An analysis of the age subgroups showed a high correlation between meteorological and geomagnetic activity indicators, and a number of indicators for assessing health condition in the meteorological patient subgroup of men below 45 years of age (table 4). 
There is a direct correlation of indicators for this subgroup:

1) Geomagnetic activity index - Upper blood pressure

2) Air temperature - Lower blood pressure

3) Air temperature - Feeling of happiness

There is reverse correlation of indicators revealed:

4) Air temperature - NPV

5) Air humidity - Upper blood pressure

6) Air humidity - Lower blood pressure

7) Air temperature - General health condition (subjective assessment)

The main factors affecting the health in this subgroup are temperature and humidity. A geomagnetic activity increase leads to an increase of the upper blood pressure. An air temperature increase leads to a decrease in NPV, worsens the subjective health assessment while enhancing the feeling of happiness, and an increase in humidity negatively affects blood pressure.

Patients died after hospitalization were marked in a special group. There is a significant tightness of the correlation between the duration of the magnetic storm, heart rate and pulse, as well as the average air temperature and blood pressure. Thus, the main geomagnetic and meteorological factors of the patients with tough diseases caused a fatal outcome were the steady-state temperature regime and the prolonged magnetic storm (table 5).

According to the additional information from the medical examination results of this group (including after an autopsy), $47 \%$ of those who died had diabetes mellitus, $53 \%$ of patients had recurrent myocardial infarction. $60 \%$ of patients died on the day of admission to the ICDC by ambulance, $13 \%$ of patients died a day after admission, the rest died 3-6 days after admission to the ICDC.

Table 3 Spearman rank correlation coefficient for women (aged up to 70) with ICD I20 Angina pectoris diagnosis $(\mathrm{n}=94)$. Noted correlations significant at level $\mathrm{p}<0.05000$

\begin{tabular}{|l|c|c|c|c|c|}
\hline \multicolumn{1}{|c|}{ Indicator } & $\begin{array}{c}\text { Geomagnetic } \\
\text { activity index }\end{array}$ & $\begin{array}{c}\text { Magnetic storm } \\
\text { duration (days) }\end{array}$ & Air temperature & $\begin{array}{c}\text { Atmospheric } \\
\text { pressure }\end{array}$ & Air humidity \\
\hline Functional health assessment \\
\hline Respiratory rate & 0.047552 & -0.520621 & -0.007767 & -0.203327 & 0.096331 \\
\hline Heartbeat rate & 0.130582 & -0.314192 & 0.090273 & -0.071904 & -0.053076 \\
\hline Pulse & 0.130582 & -0.314192 & 0.090273 & -0.071904 & -0.053076 \\
\hline Upper blood pressure & 0.004462 & -0.639605 & -0.116796 & 0.022798 & 0.051080 \\
\hline Lower blood pressure & 0.011836 & 0.011012 & -0.169077 & 0.114657 & 0.081124 \\
\hline Subjective health assessment & \multicolumn{5}{|l|}{} \\
\hline General health condition & 0.143208 & -0.234861 & 0.059230 & -0.232049 & -0.027694 \\
\hline Heavy physical work & -0.066541 & 0.318673 & 0.036704 & -0.047200 & -0.030943 \\
\hline Normal physical work & 0.015750 & 0.614796 & 0.083600 & -0.077077 & -0.136693 \\
\hline $\begin{array}{l}\text { How painful was the } \\
\text { work for you? }\end{array}$ & 0.191678 & -0.105961 & 0.029155 & -0.142757 & -0.048822 \\
\hline How long did it long? & 0.112950 & -0.105961 & 0.098623 & -0.154415 & -0.103558 \\
\hline How alert were you? & -0.052683 & 0.102806 & -0.088001 & 0.031124 & 0.095520 \\
\hline How anxious were you? & 0.098084 & -0.194110 & 0.012940 & -0.163365 & 0.092694 \\
\hline Did you feel depressed? & 0.140546 & 0.138154 & -0.007513 & -0.181516 & 0.081819 \\
\hline Did you feel relaxed? & 0.119477 & 0.637479 & 0.033711 & -0.119818 & -0.064958 \\
\hline Did you feel happy? & 0.132236 & 0.637479 & -0.087017 & -0.090792 & 0.065689 \\
\hline Did you feel tired? & -0.014088 & -0.477661 & -0.012979 & 0.059280 & 0.052947 \\
\hline $\begin{array}{l}\text { Do you feel the climate } \\
\text { change? }\end{array}$ & 0.085483 & 0.079249 & -0.017883 & -0.057645 & -0.020825 \\
\hline
\end{tabular}


Table 4 Spearman rank correlation coefficient for the group of meteosensitive men aged up to 45 years $(n=15)$.

Noted correlations significant at level $\mathrm{p}<0.05000$

\begin{tabular}{|c|c|c|c|c|c|}
\hline Indicator & $\begin{array}{c}\text { Geomagnet } \\
\text { ic activity } \\
\text { index }\end{array}$ & $\begin{array}{l}\text { Magnetic storm } \\
\text { duration (days) }\end{array}$ & Air temperature & $\begin{array}{l}\text { Atmospheric } \\
\text { pressure }\end{array}$ & Air humidity \\
\hline \multicolumn{6}{|c|}{ Functional health assessment } \\
\hline Respiratory rate & -0.180686 & 0.274175 & -0.592622 & 0.278767 & 0.461038 \\
\hline Heartbeat rate & 0.125139 & 0.126872 & -0.352424 & -0.054024 & 0.227123 \\
\hline Pulse & 0.125139 & 0.126872 & -0.352424 & -0.054024 & 0.227123 \\
\hline Upper blood pressure & 0.569696 & -0.025346 & 0.411441 & 0.028634 & -0.577093 \\
\hline Lower blood pressure & 0.170921 & -0.406888 & 0.646805 & 0.035359 & -0.585639 \\
\hline \multicolumn{6}{|l|}{ Subjective health assessment } \\
\hline General health condition & -0.147920 & 0.388354 & -0.600679 & -0.082838 & 0.305272 \\
\hline Heavy physical work & 0.000000 & 0.416667 & -0.506370 & 0.152078 & 0.177424 \\
\hline Normal physical work & 0.000000 & 0.416667 & -0.506370 & 0.152078 & 0.177424 \\
\hline $\begin{array}{l}\text { How painful was the work } \\
\text { for you? }\end{array}$ & 0.276733 & -0.113228 & 0.378412 & 0.378828 & -0.309950 \\
\hline How long did it long? & 0.173690 & 0.284268 & -0.194325 & 0.367463 & -0.043231 \\
\hline How alert were you? & 0.000000 & -0.416667 & 0.506370 & -0.152078 & -0.177424 \\
\hline How anxious were you? & 0.276733 & -0.113228 & 0.378412 & 0.378828 & -0.309950 \\
\hline Did you feel depressed? & 0.276733 & -0.113228 & 0.378412 & 0.378828 & -0.309950 \\
\hline Did you feel relaxed? & 0.276733 & -0.113228 & 0.378412 & 0.378828 & -0.309950 \\
\hline Did you feel happy? & 0.147920 & -0.388354 & 0.600679 & 0.082838 & -0.305272 \\
\hline Did you feel tired? & 0.000000 & -0.416667 & 0.506370 & -0.152078 & -0.177424 \\
\hline
\end{tabular}

Table 5 Spearman rank correlation coefficient among patients with letal outcome in 2017. $(n=15)$. Noted correlations significant at level $\mathrm{p}<0.05000$

\begin{tabular}{|l|c|c|c|c|c|}
\hline \multicolumn{1}{|c|}{ Indicator } & $\begin{array}{c}\text { Geomagnetic } \\
\text { activity index }\end{array}$ & $\begin{array}{c}\text { Magnetic storm } \\
\text { duration (days) }\end{array}$ & Air temperature & $\begin{array}{c}\text { Atmospheric } \\
\text { pressure }\end{array}$ & Air humidity \\
\hline Functional health assessment \\
\hline Respiratory rate & 0.1468 & 0.5121 & -0.1298 & 0.3541 & 0.0090 \\
\hline Heartbeat rate & 0.2380 & 0.5715 & -0.0483 & 0.1761 & -0.2757 \\
\hline Pulse & 0.2380 & 0.5715 & -0.0483 & 0.1761 & -0.2757 \\
\hline Upper blood pressure & -0.1303 & 0.2177 & -0.6028 & 0.1563 & 0.4700 \\
\hline Lower blood pressure & -0.1998 & 0.0918 & -0.5254 & -0.0636 & 0.3372 \\
\hline
\end{tabular}

\section{CONCLUSION}

Geomagnetic and meteorological factors are quite diverse and have a complex effect on the health of most patients with cardiovascular diseases $[6,14]$.

The study carried out present the picture of severe cases of patients with cardiovascular diseases admitted for treatment to a large interregional clinical center. Patients included in the analyzed sample have been in a long period of CVD treatment and prolonged use of cardiac drugs, which reduces their meteosensitivity. However, this type of patients reflect the level of meteorological and geomagnetic influences, thus it may become a part of important clinical research.

Statistical analysis of the influence was carried out using the data of the general sample, within 5 thousand patients, and for individual groups formed on the basis of the clinical form of the disease, gender, age, as well as the internal uniformity criteria.

The larger group did not reveal any statistical relationship between the functional health condition, subjective health assessment and meteorological indicators, and indicators of geomagnetic.

The statistically significant effect of meteorological and geomagnetic factors on the functional state and its 
subjective assessment, i.e. high meteosensitivity of patients was detected in groups of women with a diagnosis of Angina pectoris aged up to 46. The main meteorological and geomagnetic factors for these groups were the magnetic storm duration and the atmospheric pressure magnitude.

Increased meteosensitivity characterises men aged below 45. This is explained by the initial stage of CVD with a short period of taking cardiac drugs, reducing the influence of the analyzed factors. The main meteorological and geomagnetic factors for this group were temperature and air humidity.

Statistical analysis revealed the fact of lethal factors including the magnetic storm duration and air temperature conditions.

All groups of patients are considered meteosensitive according to indicators of subjective health assessment, than in terms of functional state of health.

\section{REFERENCES}

[1] Y.I. Gurfinkel, L.M. Parfenova, Influence of geomagnetic disturbances on heart rhythm and its ectopic activity, Proceedings of the International seminar Biological effects of solar activity, Pushchino-na-Oke, 2004, p. 20.

[2] V.E. Milyukov, T.S. Zharikova, Criteria for the formation of age groups of patients in medical research, Clin. Med. 11 (2015) 5-11.

[3] Schedule of the weather - 2019. Access to (OOO) "Raspisanie Pogody". Retrieved from: https://rp5.ru

[4] B.A. Revich, D.V. Shaposhnikov, M.A. Podol'naya et al., Heat waves in the southern cities of the European part of Russia as a risk factor for premature mortality, Probl. of forecasting 2 (2015) 55-67.
[5] B.A. Revich, D.V. Shaposhnikov, High air temperatures in cities as a real threat to public health, in: Climate change and population health in Russia in the XXI century, Department of preventive med. of the Russ. Acad. of med. Sci., Moscow, 2004.

[6] M.I. Smirnova, V.M. Gorbunov, G.F. Andreeva, Influence of seasonal meteorological factors on morbidity and mortality from cardiovascular and bronchopulmonary diseases, Preventive med. 6 (2012) 76-86.

[7] T.K. Breus, S.M.Chibisov, R.M. Baevskij et al., Chronostructure of heart biorhythms and environmental factors, Peoples ' friendship Univer. of Russ. press, Moscow, 2002, 232 p.

[8] S.M. Chibisov, Space and biosphere: influence of magnetic storms on chronostructure of biological rhythms, Bull. of the Peoples ' friendship Univer. of Russ. Ser. Med. 3 (2006) 35-44.

[9] 36-Item Short Form Survey (SF-36). Retrieved from: https://www.rand.org/healthcare/surveys_tools/mos/36-item-short-form.html

[10] R.G.D. Macnee, A. Tokai, The development of a method to determine the burden of climate change on different health outcomes at a local scale: A case study in Osaka Prefecture, Japan, Environ. Syst. and Decisions 37(3) (2017) 309-319.

[11] National Oceanic and Atmospheric Administration. Retrieved from: https://www.noaa.gov

[12] J. Vencloviene, R. Babarskiene, The effect of solargeomagnetic activity during and after admission on survival in patients with acute coronary syndromes, Int. J. of Biometeorol. 58 (2014) 1295-1303. 